\title{
THE ROLE OF THE LIMITED PARTNER DEEMING PROVISION IN THE INCOME TAX ACT: DOES SECTION 24H(2) ACHIEVE ITS INTENDED PURPOSE?
}

\section{$1 \quad$ Introduction}

The 1990s brought the announcement that National Treasury plans to rewrite the entire Income Tax Act 58 of 1962 (the "Act") (Temkin "Income Tax Act to be Rewritten" 17 February 2009 http://www.taxtalkblog. $\mathrm{com} / \mathrm{p}=2252$ (accessed 2013-12-04)). The rationale for this ambitious endeavour was founded on the practical difficulties encountered with applying an Act that what was little more than a collection of ad hoc sections. Nothing further was said of this objective until 2005, when the Finance Minister confirmed that the rewrite remained a long-term goal, although he was uncertain when the process would begin (Temkin 17 February 2009 http://www.taxtalkblog. com/?p=2252 (accessed 2013-12-04)). In 2010, it was stated that the rewrite of the Act would begin with the tax treatment of employment income (South African Revenue Service Budget 2009/10: Tax Proposals 2009/10 16-17).

The potential rewrite of the Act is an opportune catalyst to investigate the continued usefulness or otherwise of section $24 \mathrm{H}(2)$, and the role it has assumed in the tax treatment of partnerships - particularly limited partnerships - in South African law. This paper questions whether South African law needs this particular provision. In doing so, I question whether the doubts that provided the impetus for the introduction of this section are sound, or whether the section only serves to raise more questions than it answers.

\section{$2 \quad$ Why was section $24 \mathrm{H}(2)$ introduced?}

Section $24 \mathrm{H}(2)$, and section $24 \mathrm{H}$ as a whole, was introduced into the Act in 1988. Section $24 \mathrm{H}(2)$ provides that:

"(2) Where any trade or business is carried on in partnership, each member of such partnership shall, notwithstanding the fact that he may be a limited partner, be deemed for the purposes of this Act to be carrying on such trade or business."

The term "limited partner" is defined in section $24 \mathrm{H}(1)$ of the Act as follows:

“(1) For the purposes of this section, 'limited partner' means any member of a partnership en commandite, an anonymous partnership or any similar partnership, if such member's liability towards a creditor of the partnership is 
limited to the amount which he has contributed or undertaken to contribute to the partnership or is in any other way limited."

This paper shall refer to the partner en commandite and the anonymous or silent partner as the "limited partner". A partnership en commandite is one in which the partner en commandite's identity is not disclosed to the partnership creditors (South African Revenue Service Budget 2009/10: Tax Proposals 2009/10 16-17). Upon dissolution of the partnership, such partner's liability is limited to the extent of his contribution made to the partnership (South African Revenue Service Budget 2009/10: Tax Proposals 2009/10 16-17). An anonymous or silent partnership is similar in that the disclosed partners manage the partnership business while the identity of the silent partner is not disclosed to the partnership creditors (South African Revenue Service Budget 2009/10: Tax Proposals 2009/10 16-17). In the event of the dissolution, the silent partner's position is the same as that of an ordinary partner vis-a-vis his co-partners - he is liable for his pro rata share of the partnership debts (South African Revenue Service Budget 2009/10: Tax Proposals 2009/10 16-17). Provided that the silent partner and the partner en commandite do not publicly participate in the management of the partnership business, they cannot be sued by creditors of the partnership for the partnership debts (Barker \& Co v Blore 1908 TS 1156; and Sabatelli v St Andrew's Building Society 1933 WLD 55).

The purpose behind the introduction of section $24 \mathrm{H}(2)$ is to place it beyond doubt that the limited partner is carrying on the business of the partnership. According to the Explanatory Memorandum (National Treasury Explanatory Memorandum to the Income Tax Bill (1988) 22), the deeming provision of section $24 \mathrm{H}(2)$ is necessary in order to allay any doubts that the limited partner - particularly the partner en commandite - may himself not be carrying on a trade, as understood in terms of the Act. The source of such doubts, it is believed, is the fact that the limited partner of a partnership must not disclose his existence to creditors of the partnership to avoid losing the indemnity he enjoys against creditors' claims (Pothier (translated by Tudor) A Treatise on the Contract of Partnership (1854) $75 \mathrm{fn}$ 102). Moreover, such partner must not publicly be involved in the management of the partnership business or also risk losing his indemnity (Pothier (translated by Tudor) $A$ Treatise on the Contract of Partnership $75 \mathrm{fn} 102$ ). It seems that these doubts came to light in 1988 in the wake of numerous tax-avoidance schemes involving en commandite partnerships (Editorial "Closing more Doors" 1988 37(2) The Taxpayer 128 ).

These doubts do not extend to all limited partners. Limited partners may be involved in the management of the partnership business. However, if limited partners wish to retain their indemnity, their status as partners must not be disclosed to the outside world (Lamb Bros v Brenner and Company (1885-1887) 5 EDC 152 161). Limited partners who do so engage in management activities would clearly be carrying on the trade of the partnership as understood in the definition of "trade" under section 1 of the Act. There is accordingly no doubt that such partners would have access to the deductions under section 11, provided all of the other requirements of the section are met. The position is not as clear, it would seem, in respect of 
limited partners who completely refrain from any involvement in the management of the partnership business.

Arguably, this would leave room for National Treasury's doubts to take root. But, are these doubts defensible?

\section{$3 \quad$ Are national treasury's doubts sound?}

In order to determine this, it is important to have an understanding of the definition of "trade" and how it has been interpreted over the years.

\section{The interpretation of "trade"}

"Trade" is defined in section 1 of the Act as including:

"every profession, trade, business, employment, calling, occupation or venture, including the letting of any property and the use of or the grant of permission to use any patent ... or any design ... or any trade mark ... or any copyright ... or any other property which is of a similar nature."

The term "trade" features in a number of places in the Act. The sections which are relevant for the purposes of this paper are set out as follows. First, it features in the preamble to section 11(a) of the Act, which reads:

"11 General deductions allowed in determination of taxable income: For the purpose of determining the taxable income derived by any person from carrying on any trade within the Republic, there shall be allowed as deductions from the income of such person so derived - (a) expenditure and losses actually incurred in the Republic in the production of the income, provided such expenditure and losses are not of a capital nature."

The term is again found at section $23(\mathrm{~g})$, which states:

"23. Deductions not allowed in determination of taxable income - No deductions shall in any case be made in respect of the following matters, namely -

(g) any moneys, claimed as a deduction from income derived from trade, to the extent to which such moneys were not laid out or expended for the purposes of trade".

What is meant by "trade" is also pivotal for the purposes of section 20 , produced below:

"20 Set-off of assessed losses: (1) For the purpose of determining the taxable income derived by any person from carrying on any trade, there shall, subject

to section 20A, be set off against the income so derived by such person -

(a) any balance of assessed loss incurred by the taxpayer in any previous year which has been carried forward from the preceding year of assessment;

(b) any assessed loss incurred by the taxpayer during the same year of assessment in carrying on any other trade either alone or in partnership with others, otherwise than as a member of a company the capital whereof is divided into shares ..."

As we begin to interpret the definition, it is immediately apparent that the definition is very broad - perhaps even so broad that it loses its usefulness. 
As a result, a plethora of case law has developed over the years to assist in the interpretation of the definition.

The South African Revenue Service ("SARS") attempted to provide some guidance as to its interpretation with the issue of Interpretation Note 33. The Interpretation Note relates to the interpretation of "trade" as it is in found in section 20(1)(a) of the Act. In terms of the approach taken to the interpretation of the definition, ITC 770 ((1953) 19 SATC 216) cast the net wide by stating that the definition is "obviously intended to embrace every profitable activity and ... I think should be given the widest possible interpretation".

A deeper analysis of the interpretation of the "trade" definition produces a list of some of the more widely accepted principles when it comes to the understanding of what it means to be carrying on a trade under the Act.

The first of these is that the taxpayer must have undertaken some form of a positive or active step in its attempt to convince the Court that it was trading. In ITC 1476 ((1989) 52 SATC 141), the Court noted that it is trite that an active step is at least required in order for a taxpayer company to be carrying on a trade. Kirk-Cohen $\mathrm{J}$ elaborates and says:

"In my view, the carrying on of a trade involves an active step - something more than merely watching over existing investments which are not, and are not intended or expected to be, income producing during the year in question" (ITC 1476 148).

The Court in CSARS v Contour Engineering (Pty) Ltd ((1999) 61 SATC 447) further elaborated on the steps the Court had in mind when conducting the trade enquiry. The taxpayer has to exhibit something more than just planning for its future in order to convince the Court that it was trading. A positive act is required.

A second principle is that investment activities do not constitute the carrying of a trade, unless the taxpayer is a money-lender. In ITC 512 ((1941) 12 SATC $246(U))$, the taxpayer asserted that, in addition to his occupation as auctioneer, he was carrying on the business of a financier and investor when he would gain a return from investing his surplus funds into bonds, properties and loans. The Court rejected that the taxpayer was trading, stating that the taxpayer's actions amounted to the investment of savings. According to the Court:

"It is clear that these [accumulated funds] are savings in the ordinary way which are being put out on investment."

The Court held that the taxpayer's actual trade was only that of an auctioneer - as evidenced by the taxpayer's tardiness in tacking on his financier operations to his business activities during testimony.

It is not clear how the Court came to this conclusion. While the definition of "trade" is briefly mentioned, no definition of "savings" or "investments" is considered. The Court seems to work from an instinctive understanding of what a trade encompasses - the taxpayer's occupation meeting this standard while his "investment" activities not - while presuming that the concepts of investment and savings are anathema to trade. While this 
position may not be incorrect, it is not appropriate for such oblique inferences to go unaddressed.

The question of investment versus trade activities arose again in ITC 1275 ((1978) 40 SATC 197 (C)). The individual taxpayer sought to deduct expenses he had incurred in dealing with his investment portfolio. These investments had remained unchanged over the five-year period in question. In rejecting the taxpayer's argument that he was engaged in trade, the Court noted that the taxpayer could not even identify the nature of his stated trade. This proved to be fatal to his argument. In reaching the conclusion that

"the law does not allow a taxpayer who derives his income from investments to deduct from his income expenses he incurs in watching over those investments, however wisely incurred those expenses may be",

the Court relied on ITC 512 and ITC 957 ((1960) 24 SATC 637). ITC 957 sets out the necessary requirements for a business of money-lending to be conducted. Neither the term "trade" nor "investment" is defined in ITC 1275. Presumably this is because of the Court's reliance on the authority of ITC 512 in denying the possibility of investments falling within the "trade" definition.

A third principle is that the taxpayer will not be engaged in a trade if the taxpayer is a passive investor. This principle may possibly be subsumed by the second principle, but it has been specifically mentioned by the courts. This was the case in CSARS v Tiger Oats ([2003] 2 All SA 604 (SCA)). The Supreme Court of Appeal concluded that the taxpayer was not a mere passive investor as the taxpayer was intimately involved in the business of its subsidiaries. Accordingly, the taxpayer was engaged in a trade. This was not the case in ITC $1802((2005) 68$ SATC 67). The taxpayer company in ITC 1802 was found to be decidedly lacking in comparison to the taxpayer in Tiger Oats. The Court held that the taxpayer in ITC 1802 was even more inactive than the word "passive" would allow. The taxpayer had no bank accounts in its own name, the payment of interest to it by its subsidiaries was erratic, and the taxpayer had not made any loans to its subsidiaries or received any loans. Accordingly, the taxpayer was not engaged in trade during the relevant tax year.

Now that the principles relating to the interpretation of the "trade" definition is understood, it becomes easier to analyze whether a limited partner, who does not engage in the management of the partnership business at all, can be said to be carrying on the trade of the partnership.

\section{Limited partnership and the "trade" requirement}

This question can be directly addressed by the case of Burgess $v$ CIR (1993 (4) SA $161(\mathrm{~A})$ ). The issue before the then Appellate Division was whether the taxpayer, as a limited partner, was engaged in a trade.

The taxpayer was a partner en commandite in a partnership which had Fenton Investments (Pty) Ltd ("Fenton") as the disclosed partner. Fenton devised a scheme which, in essence, involved the short-term investing of borrowed funds into an asset expected to increase in value and this in the hope of realizing such increased value as profit. The en commandite 
partnership was put in place in order to limit the potential losses of the scheme to the value of the taxpayer's partnership contribution should the asset not perform as expected. The value of the taxpayer's partnership contribution was a bank guarantee of R425 000 .

It so happened that the asset did not perform as expected, resulting in the partnership making a loss by the end of the taxpayer's tax year. The taxpayer sought to deduct his share of the partnership loss from his personal income.

The Commissioner argued against such deduction on the basis that the taxpayer was not engaged in a trade. The reasons for this were: first, as the taxpayer's main purpose for engaging in this transaction was to obtain a tax advantage through a tax deferment, the taxpayer was not carrying on a trade for the purposes of the Act. Secondly, the taxpayer's involvement in the scheme amounted to an investment which did not constitute the carrying on of a trade.

Section $24 \mathrm{H}$ was not yet in operation during the year of assessment in question.

On the Commissioner's first argument, the Court disagreed that a taxmotivated purpose would have the effect of removing the taxpayer's activities from the realm of carrying on a trade altogether. According to the Court, if the taxpayer was engaged in trade, his reasons for doing so were irrelevant. In any event, the Court was convinced that the taxpayer's main purpose for entering into the scheme was to make a profit.

The Commissioner also proved unsuccessful in convincing the Court of its second argument. In considering the argument, the Court considered the definition of the term "trade" as defined in section 1 of the Act:

"trade includes every profession, trade, business, employment, calling, occupation or venture, including the letting of any property and the use of or the grant of permission to use any patent ... or any design ... or any trade mark ... or any copyright ... or any other property which is of a similar nature".

After noting that the definition of trade is to be given the widest possible interpretation as encompassing "any profitable activity" (ITC 77019 SATC 216 217), the Court considered the taxpayer's argument that his involvement in the scheme constituted a "venture" as included in the "trade" definition. The Court relied on the definition of "venture" as enunciated in ITC 368 (9 SATC 211) which was supported by numerous dictionary definitions. It was defined as:

"[A] transaction in which a person risks something with the object of making a profit" (ITC 368212 ).

The Court held that the taxpayer was engaged in a "venture" as understood in the above sense. The taxpayer had subjected the value of his bank guarantee to substantial risk in his desire to make a profit.

The Court concluded then that the limited partner was engaged in a trade through his sole activity of providing funds to participate in a scheme that may or may not result in a profit. 


\section{Burgess and the principles of "carrying on a trade"}

The Burgess case does not fit neatly within the widely accepted principles of what it means to carry on a trade under the Act, as was set out above. The Burgess judgment raises a number of questions as to what is that makes the taxpayer in Burgess different from the many other taxpayers who carried out similar activities, and yet were found not to be carrying on a trade.

What distinguishes the activity undertaken in Burgess from that of investment activities? Also, what sets the taxpayer in Burgess apart from a mere passive investor? The sole activity undertaken by Burgess was the provision of capital - in the form of the bank guarantee of R425 000 - to the limited partnership. Burgess was set to receive an amount of interest on such investment made.

It becomes difficult to distinguish Burgess from the taxpayer in ITC 512. In both cases, the taxpayers were involved in professions. The taxpayer in ITC 512 was an auctioneer, while Burgess was a director of several companies. Both taxpayers had decided to invest their surplus funds in a manner that it was hoped would result in a profitable return for the taxpayer. And yet, only the actions of Burgess amounted to the carrying on of a trade.

Similarly, the difference between Burgess and the taxpayer in ITC 1275 is not clear. Again here, both Burgess and the taxpayer had made investments with the hope of realizing a return on such investments. While the taxpayer in ITC 1275 had continuity in his actions that Burgess lacked, the Court was of the view that the unchanging nature of the taxpayer's portfolio in ITC 1275 meant that the taxpayer was not engaged in a trade. The taxpayer was merely watching over investments, the Court found. And yet, it is difficult to see how Burgess was also not merely watching over his investment as he waited anxiously to see whether the Fenton scheme would realize the return he had been promised.

Finally, a further case that bears a marked similarity to Burgess and yet bore a different outcome is ITC 496 (12 SATC 132 (U)). In ITC 496, the taxpayer was part of a group of companies. The taxpayer's main trade was that of a retail business. The taxpayer made a loan to its subsidiary with the purpose that the subsidiary use it to erect a building within which the taxpayer was to conduct its retail trade. The Court found that the interest the taxpayer so earned from the loan was neither part of the taxpayer's trade nor a new trade of providing finance. The loan was an investment made by the taxpayer.

It is difficult to see how the provision of funds by Burgess is different from the funds provided by the taxpayer in ITC 496 . While the funds provided by Burgess admittedly was not a loan as was the case in ITC 496, is the degree of risk to which the funds were exposed really all that is needed to distinguish the two cases? And, if we are to accept that, was the loan advanced to the subsidiary of the taxpayer in ITC 496 not also exposed to some degree of risk given that the subsidiary's finances could have deteriorated such that the subsidiary could not repay the loan?

These questions give rise to the bigger question - what is that made Burgess different from all the other taxpayers discussed above? Could it be 
as simple as the interposition of the limited partnership that convinced the Court that Burgess was carrying on the trade of the partnership? Was this enough to transform Burgess's sole activity of providing funds from the actions of a mere passive investor merely watching over his investments into a taxpayer carrying on a trade under the Act?

Would the Court's answer have been the same if the taxpayer in Burgess was not an individual but rather a company? Would the Court have been satisfied then that the sole action of providing funds towards the scheme was an active step that amounted to more than the mere watching over of investments as a passive investor would do?

These questions lead the author to conclude that a broader interpretation of the definition of "trade" is at play in the Court's approach in Burgess versus the Court's approach in ITC 1476, for example. If we can accept that in certain instances the sole action of providing funds is enough to convince the Court that the taxpayer is engaged in a trade, we can also accept then that a limited partner can be engaged in the trade of the partnership without being involved in the management of the partnership or having his name disclosed to the creditors of the partnership. It would seem then that the doubts National Treasury held, and which led to the introduction of section $24 \mathrm{H}(2)$, were unfounded.

If we are prepared to accept all this, then why do we need section $24 \mathrm{H}(2)$ at all then? Perhaps the answer lies in the other way in which section $24 \mathrm{H}(2)$ has been used - namely, in the manner in which section $24 \mathrm{H}(2)$ has featured in cases involving international tax.

\section{4 \\ A new purpose for section $24 \mathrm{H}(2)$ in international $\operatorname{tax}$ ?}

The inclusion of section $24 \mathrm{H}(2)$ has brought about an interesting development in the international tax arena. The Free State High Court in Grundlingh v CSARS ((2009) 72 SATC 1) relied on section $24 \mathrm{H}(2)$ in determining whether the income earned by the taxpayer was "business income" under Article 7 of the double taxation agreement ("DTA") between South Africa and Lesotho. Although the Court ultimately decided that Article 7 was not applicable under the circumstances because the Lesotho-based partnership was held not be an "enterprise liable to tax" in Lesotho, and that somehow this gave rise to an obligation under Article 22 for South Africa to provide tax relief for the taxation paid in Lesotho, the Court nonetheless made use of section $24 \mathrm{H}(2)$ to determine that the taxpayer carried on the business of the partnership.

The Grundlingh judgment has been criticized for the reasoning used by the Court to come to the conclusion which is ultimately correct - the assessments raised by SARS should stand. Hattingh ("The Tax Treatment of Cross-border Partnerships under Model-based Bilateral Double Tax Conventions: A Case \& Methodology" 2010 Cambridge Student LR 16 28) argues that the reasoning and the decision of the earlier decision by the Tax Court (ITC 1819 (2007) 69 SATC 150) is correct in that Article 7 did apply under the circumstances. The parties agreed that the taxpayer was a 
resident of South Africa and that his activities in Lesotho created a permanent establishment there. It would seem that, as the Court in Grundlingh had dealt only with addressing the taxpayer's flawed interpretation of Article 7 - that the enterprise in question was the Lesotho partnership which did not have a permanent establishment in South Africa the Tax Court's finding that Article 7 did in fact apply to the facts, but in respect of a different taxpayer (ie, the resident partner), would still stand. The enterprise carried on by a resident of South Africa was the South African resident and individual partner's participation in the Lesotho partnership. Also, such participation amounted to a permanent establishment in Lesotho. Such an interpretation would be necessary in order to make sense of the Court in Grundlingh's decision that Article 22 of the DTA should apply to the circumstances of the case. Article 22 imposes an obligation on South Africa to provide relief from the double taxation. Hattingh (2010 Cambridge Student LR 28) notes that Article 22 of the DTA can only apply if a distributive rule of the DTA applies. If the court is not convinced that Article 14 applies then it must be Article 7 that assigns the taxing rights between the Contracting States.

Notwithstanding the issues around the reasoning of the Courts in Grundlingh, it is nonetheless clear that section $24 \mathrm{H}(2)$ played a part in both Courts' reasoning in determining the applicability or otherwise of Article 7 of the DTA. The question remains: should section $24 \mathrm{H}(2)$ be used in this manner?

The concern about using section section $24 \mathrm{H}(2)$ in this manner is rooted in the fact that the section is a deeming provision. This means that a legal fiction is imposed by legislative means, and usually for a particular purpose. The purpose for the introduction of section $24 \mathrm{H}(2)$, as discussed above, is to allow the limited partner to deduct the expenses of the partnership when determining the taxable income of such limited partner. Gutuza argues that this deeming provision should be used only to meet this particular purpose (Gutuza "Taxing the Partners of a Foreign Partnership" 2008125 SALJ 514 $519)$. It is inappropriate to use this section to meet a different purpose - as was the case in Grundlingh and ITC 1819 (Gutuza 2008125 SALJ 519). In these cases, the section was used to classify the partner's income for the purposes of applying the DTA. Gutuza's argument is convincing in that these two purposes are manifestly different and completely unrelated. Moreover, logic dictates that, if it was meant for this legal fiction to serve a dual purpose, such intent should be stated directly.

Gutuza further argues that the empowering article in the DTA, which the Court used to resort to domestic law, does not seem to allow the use of domestic deeming provisions (Gutuza 2008125 SALJ 517). The empowering provision so used is Article 3(2) of the South Africa - Lesotho DTA, which provides:

"In the application of the provisions of this Agreement by a Contracting State, any term not otherwise defined herein shall, unless the context otherwise requires, have the meaning which it has under the laws of that State concerning the taxes which are the subject of this Agreement."

This issue has not come before a South African court. The issue has, however, been raised internationally. The Canadian Supreme Court in The 
Queen v Melford Investments Inc ([1982] 2 SCR 504) considered whether a domestic deeming provision may be used in the application of a DTA. The issue before the Court was whether the later amendment in Candian law, which deemed guarantee fees to be interest, had the effect of changing the meaning of the term "interest" under the applicable DTA.

The Court rejected the use of the deeming provision in interpreting the provisions of the DTA. The Court began by determining the intention of the parties to the DTA. Such intention was determined by examining the extent of Canada's taxing rights under the DTA, and whether the deeming provision would extend such rights. The Court found that the use of the deeming provision in the interpretation of the DTA had the effect of extending Canada's taxing rights. Accordingly, the DTA would be interpreted without the deeming provision.

The second issue before the Court was which domestic law was to be applied by the Court under Article 3(2). According to Estay J:

\footnotetext{
"The question is ... whether the collateral legislative action in connection with the Income Tax Act has the effect of amending the 1956 statute. The suggestion that it does have such an effect is startling. There are 26 concluded and 10 proposed tax conventions, treaties or agreements between Canada and other nations of the world. If the submission of the appellant is correct, these agreements are all put in peril by any legislative action taken by Parliament with reference to the revision of the Income Tax Act. For this practical reason one finds it difficult to conclude that Parliament has left its own handiwork of 1956 in such inadvertent jeopardy. That is not to say that before the 1956 Act can be amended in substance it must be done by Parliament in an Act entitled 'An Act to Amend the Act of 1956'. But neither is the converse true that is that every tax enactment, adopted for whatever purpose, might have the effect of amending one or more bilateral or multilateral tax conventions without any avowed purpose or intention so to do" (author's own emphasis) (The Queen v Melford Investments Inc supra 513514).
}

The Supreme Court thus adopted the view that the Article 3(2) equivalent under the Canada - Germany DTA referred to the domestic law of a state as existed at the time of the conclusion of the DTA (known as the "static approach") (The Queen v Melford Investments Inc supra 513). The Court refused to accept that the domestic law as at the time of the application of the DTA (known as the "ambulatory or dynamic approach") was applicable because this would mean that that "subs. (2) authorizes Canada or Germany to unilaterally amend the tax Treaty from time to time as their domestic needs may dictate" (The Queen v Melford Investments Inc supra 513).

A similar issue came before the Netherlands Hoge Raad in the form of two cases decided on 5 September 2003 (Hoge Raad, September 5, 2003, BNB 2003/379c and 381c). Certain domestic legislation in the Netherlands, introduced in 1997, deemed the shareholders of a company who did work for it to receive an annual "habitual" wage of NLG 150000 on the basis that the company was the employer of such shareholder. At issue before the Court in both instances was the interpretation of the undefined terms "wages", "derived by" and "employment" as used in Article 15 of the DTA between the Netherlands and Belgium, concluded in 1970. 
According to the Court, domestic deeming provisions may be used in certain instances. However, domestic deeming provisions may not be used when the effect of such provisions is to extend the taxing rights of the State involved. In casu, the effect of the Netherlands deeming provision was to grant the Netherlands the right to tax fictional income that it otherwise would not have been entitled to do. It could accordingly not have been the intention of the Contracting States for the undefined terms to have the meaning ascribed to them under the Netherlands domestic deeming provisions (Kandev "Tax Treaty Interpretation: Determining Domestic Meaning under Article 3(2) of the OECD Model" 200755 Canadian Tax Journal 31 55). The Court then proceeded to interpret the undefined terms without reference to the Netherlands domestic deeming provision.

Kandev is of the view that the Canadian Supreme Court in Melford Developments would have applied the deeming provision to the DTA were it not for the Court's adoption of the static approach to the interpretation of the Article 3(2) equivalent (Kandev 200755 Canadian Tax Journal 54). However, Sandler adopts a different view and states that the above Melford Developments and Hoge Raad cases suggest that deeming provisions cannot be applied to DTAs (Sandler The Taxation of International Entertainers and Athletes: All the World's A Stage (1995) 229).

The above discussion indicates that it is by no means settled that domestic deeming provisions - such as section $24 \mathrm{H}(2)$ - may always be used to interpret and apply DTAs.

My view on this point is that the enquiry should begin by determining the intention of the contracting parties. Did the parties intend the deeming provision to form part of the meaning to be attributed to the DTA terms? Recent case law in jurisdictions such as Canada, India and the US indicate that the DTA should be interpreted in such a way as to give effect to the intention of the contracting states (Garibay "An Analysis of the Case Law on Article 3(2) of the OECD Model (2010)" 7 July 2011 http://online.ibfd.org/kba $\mathrm{se} /$ \#topic=doc\&url=/collections/bit/html/bit_2011_08_int_2.html (accessed 2014-09-15). Such intention may be discerned from the text of the treaty itself, the domestic law of the parties and the Commentaries on the OECD Model Tax Convention as at the date of the conclusion of the treaty (Garibay 7 July $2011 \mathrm{http}: / /$ online.ibfd.org/kbase/\#topic=doc\&url=/collections/bit/html/ bit_2011_08_int_2.html (accessed 2014-09-15). The Melford Developments and Hoge Raad cases would assist in determining the limitations of the use of deeming provisions. The deeming provisions may not be incorporated if the effect is to unilaterally alter the taxing rights agreed to in the DTA.

As it applies to the cases in Grundlingh and the use that was made of section $24 \mathrm{H}(2)$, the question then becomes: did South Africa and Lesotho intend the deeming provision of section $24 \mathrm{H}(2)$ to be incorporated into the DTA between them? This intention may be discerned by examining the extent of South Africa's taxing rights under the DTA without the inclusion of the deeming provision.

There are not many cases in South Africa that deal with the taxation of cross-border partnerships. One of such cases is CIR v Epstein (1954 (3) SA 689 (A)). Both taxpayers in the Grundlingh and Epstein cases were South African residents who were partners in cross-border partnerships. The 
Appellate Division in Epstein considered the nature of the income earned by the resident partner in determining the source of the resident partner's income. The view of the Court, as stated by Centlivres $\mathrm{CJ}$, is that:

"It may be said that when there is a partnership the members of which carry on their business activities in two different countries, the income of the partnership is derived from two sources and that when one of the partners carries on his business activities in the Union his income from the partnership is derived from a source within the Union while the income of the other partner is derived from a source in a foreign country. For the income which the partner, who carries on his business activities in the Union, receives is the quid pro quo for the services he renders in the Union to the partnership" (author's own emphasis) (CIR $v$ Epstein supra 699).

According to the then Appellate Division then, the originating cause of the income earned by the taxpayer in Epstein was as a result of the services he had rendered to the partnership. The originating cause of the partner's income is not the partnership agreement itself which would determine the share of the partnership's income that the partner is entitled to receive. The source of the profits of a partnership with two partners operating in separate countries is accordingly in two countries, according to Epstein - each representing the place where the partner had exerted his efforts. The Court came to this conclusion despite the conceptual difficulty in understanding how it is that a partner could essentially be rendering a service to himself, as the partnership is not a separate legal entity (Hahlo "Taxation" 1954 Annual Survey of SA Law 292; and Gillooly "The Taxation of Partners" 1981 De Rebus 383 386).

The minority of the Court in Epstein, however, was of the view that the income earned by the taxpayer was in the nature of profits of a business. In determining that the source of the taxpayer's income was Argentina, Schreiner JA noted that what was of importance was the place where the profits of the partnership business were realized, and not where the partner himself had personally exerted himself. Schreiner JA was accordingly of the view that the originating cause of the profits from the sale of goods by the partnership was realized at the place where the goods were sold, that is, in Argentina.

It is therefore arguable that without section $24 \mathrm{H}(2)$ deeming the limited partner to be carrying on the business of the partnership, the income of a limited partner may be classified as income from personal services rendered to the partnership - as was determined by the Appellate Division in Epstein - and not income from business profits being the partner's share of the partnership's profits - as was decided by the Tax Court in ITC 1819.

The taxing rights of personal services are determined under Article 14 (now deleted in the OECD Model Tax Convention but still applicable in some of South Africa's treaties). In terms of Article 14, South Africa would have the exclusive right to tax the income of its resident unless the resident had rendered the services, or had a fixed base, in the other State. If the deeming provision were included, Article 7 dealing with the taxation of business profits would be applicable. Under Article 7, South Africa would have the exclusive right to tax the business profits of an enterprise run by its resident unless 
such business profits are attributable to a permanent establishment located in the other State.

Although the effect of the two Articles is similar, a slight advantage to South Africa might be determined. It is easier to establish where services were rendered than it is to establish whether or not a permanent establishment had been established in another State. The taxing entitlement of South Africa under Article 7 may therefore survive slightly more often than its entitlement under Article 14. There may therefore be grounds for arguing that the introduction of section $24 \mathrm{H}(2)$ has seen a shift - albeit slight - in the taxing rights between South Africa and Lesotho.

A further consideration lies in the manner in which section $24 \mathrm{H}(2)$ was introduced. If we are to accept that it was South Africa's intention to effectively override the Appellate Division decision in Epstein and to make it clear that Article 7 is now to apply to the income earned by the partners of a partnership, should this wide-sweeping and fundamental shift not have been stated somewhere? And, yet other than in the cursory reference to the section in Grundlingh and ITC 1819 and its effect on South Africa's DTAs, no other source indicates such intention or purpose for this section. How are we to accept then that this was in fact the intention when section $24 \mathrm{H}(2)$ was promulgated into law?

A second issue arises from the above discussion; namely, which law is to be considered under the auspices of Article 3(2) of the OECD Model Tax Convention. This article was amended in 1995 so as to make it clear that it is the law at the time of the application of the DTA which is to be applied by the Contracting State. However, as is clear from the above Hoge Raad cases in 2003, not all States have adopted this amended version of the Article in their DTAs. Nor does South Africa's DTA with Lesotho include the amended version of Article 3(2). As South Africa is not a member of the OECD, it is therefore not settled that South Africa will adopt an ambulatory approach to the interpretation of DTAs as advocated by the OECD.

If South Africa were to follow a static approach in applying Article 3(2), this would mean that as nine of South Africa's DTAs were signed before section $24 \mathrm{H}(2)$ came into operation, this section cannot be used as part of South Africa's domestic law when applying these DTAs to the income earned by partners (South Africa's DTAs with Germany, Grenada, Israel, Malawi, the Netherlands, Sierra Leone, Switzerland, Zambia and Zimbabwe were concluded before 1988). In the absence of section $24 \mathrm{H}(2)$, the Appellate Division decision of Epstein looms large in its ruling that the nature of the partner's income arises from the personal services he renders to the partnership.

\section{$5 \quad$ Conclusion}

Section $24 \mathrm{H}(2)$ was introduced to allay the doubts National Treasury harboured about whether the limited partner can truly be said to be carrying on the business of the partnership. It would seem that the intention here was then to allow limited partners to deduct their share of the partnership expenses under the general deduction formula. 
The Burgess case raises doubts as to whether this legislative intervention is necessary. Neither SARS nor the Court seems to share National Treasury's misgivings about the role the limited partner plays in the partnership business. It is clear that the Court is prepared to accept that even the sole activity of providing capital to a scheme designed to generate some form of a profitable return is enough to constitute the carrying on of a trade.

If section $24 \mathrm{H}(2)$ is not needed for the purposes of allowing the limited partner access to the general deduction formula under the Act, the question then becomes: what purpose does section $24 \mathrm{H}(2)$ serve?

It is postulated that recent case law in the form of ITC 1819 and Grundlingh would seem to indicate that this purpose has materialized in the international tax arena as a means to identify the type of income earned by a partner of a cross-border partnership.

The concern, however, is at what cost this purpose is achieved. Does the existence of section $24 \mathrm{H}(2)$ now mean that it is settled in our law that the income earned from resident partners of a cross-border partnership is business profits, governed by Article 7 of most DTAs concluded by South Africa? It is, of course, perfectly acceptable for South Africa to make the decision that the income a partner receives will be viewed as business profits for the purposes of applying the country's DTAs. The objection to section $24 \mathrm{H}(2)$ doing just this, is the question at what point can we confidently say that, in South Africa, it is not that every tax enactment, adopted for whatever purpose, has the effect of amending one or more bilateral or multilateral tax conventions without any avowed purpose or intention so to do?

Given that section $24 \mathrm{H}(2)$ seems to raise more issues than it solves, it is doubtful whether the section's inclusion in any future Income Tax Act would be useful.

Afton Titus

University of Cape Town 